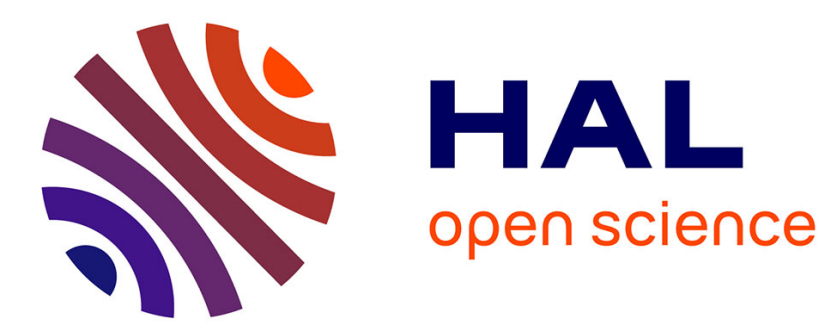

\title{
Storytelling Variants: The Case of Little Red Riding Hood
}

\author{
Edirlei Lima, Antonio L. Furtado, Bruno Feijo
}

\section{To cite this version:}

Edirlei Lima, Antonio L. Furtado, Bruno Feijo. Storytelling Variants: The Case of Little Red Riding Hood. 14th International Conference on Entertainment Computing (ICEC), Sep 2015, Trondheim, Norway. pp.286-300, 10.1007/978-3-319-24589-8_22 . hal-01758434

\section{HAL Id: hal-01758434 \\ https://hal.inria.fr/hal-01758434}

Submitted on 4 Apr 2018

HAL is a multi-disciplinary open access archive for the deposit and dissemination of scientific research documents, whether they are published or not. The documents may come from teaching and research institutions in France or abroad, or from public or private research centers.
L'archive ouverte pluridisciplinaire HAL, est destinée au dépôt et à la diffusion de documents scientifiques de niveau recherche, publiés ou non, émanant des établissements d'enseignement et de recherche français ou étrangers, des laboratoires publics ou privés. 


\title{
Storytelling Variants: The Case of Little Red Riding Hood
}

\author{
Edirlei Soares de Lima, Antonio L. Furtado, and Bruno Feijó \\ Department of Informatics - Pontifical Catholic University of Rio de Janeiro (PUC-RIO) \\ Rua Marquês de São Vicente, 225 - Rio de Janeiro - Brazil \\ \{elima, furtado, bfeijo\}@inf.puc-rio.br
}

\begin{abstract}
A small number of variants of a widely disseminated folktale is surveyed, and then analyzed in an attempt to determine how such variants can emerge while staying within the conventions of the genre. The study follows the classification of types and motifs contained in the Index of Antti Aarne and Stith Thompson. The paper's main contribution is the characterization of four kinds of type interactions in terms of semiotic relations. Our objective is to provide the conceptual basis for the development of semi-automatic methods to help users compose their own narrative plots.
\end{abstract}

Keywords: Folktales, Variants, Types and Motifs, Semiotic Relations, Digital Storytelling, Plan Recognition.

\section{Introduction}

When trying to learn about storytelling, in order to formulate and implement methods usable in a computer environment, two highly influential approaches come immediately to mind, both dealing specifically with folktales: Propp's functions [34] and the comprehensive classification of types and motifs proposed by Antti Aarne and Stith Thompson, known as the Aarne-Thompson Index (heretofore simply Index) [1,39,40].

In previous work, as part of our Logtell project [13, 14], we developed prototypes to compose narrative plots interactively, employing a plan-generation algorithm based on Propp's functions. Starting from different initial states, and giving to users the power to intervene in the generation process, within the limits of the conventions of the genre on hand, we were able to obtain in most cases a fair number of different plots, thereby achieving an encouraging level of variety in plot composition.

We now propose to invest on a strategy that is based instead on the analysis of already existing stories. Though we shall focus on folktales, an analogous conceptual formulation applies to any genre strictly regulated by conventions and definable in terms of fixed sets of personages and characteristic events. In all such genres one should be able to pinpoint the equivalent of Proppian functions, as well as of ubiquitous types and motifs, thus opening the way to the reuse of previously identified narrative patterns as an authoring resource. Indeed it is a well-established fact that new stories often emerge as creative adaptations and combinations of old stories: this is a most common practice among even the best professional authors, though surely not easy to trace in its complex ramifications, as eloquently expressed by the late poststructuralist theoretician Roland Barthes [3, p. 39]:

ICEC, p. 1, 2015.

(C) Springer-Verlag Berlin Heidelberg 2015 


\begin{abstract}
Any text is a new tissue of past citations. Bits of code, formulae, rhythmic models, fragments of social languages, etc., pass into the text and are redistributed within it, for there is always language before and around the text. Intertextuality, the condition of any text whatsoever, cannot, of course, be reduced to a problem of sources or influences; the intertext is a general field of anonymous formulae whose origin can scarcely ever be located; of unconscious or automatic quotations, given without quotation marks.
\end{abstract}

The present study utilizes types and motifs of the Aarne-Thompson's Index, under whose guidance we explore what the ingenuity of supposedly unschooled narrators has legated. We chose to concentrate on folktale type AT 333, centered on The Little Red Riding Hood and spanning some 58 variants (according to [38]) from which we took a small sample. The main thrust of the paper is to investigate how such rich diversities of variants of traditional folktales came to be produced, as they were told and retold by successive generations of oral storytellers, hoping that some of their tactics are amenable to semi-automatic processing. An added incentive to work with folktale variants is the movie industry's current interest in adaptations of folktales for adult audiences, in contrast to early Disney classic productions.

Related work is found in the literature of computational narratology [9,32] - a new field that examines narratology from the viewpoint of computation and information processing - which offers models and systems based on tale types/motifs that can be used in story generation and/or story comparison. Karsdorp et al. [26] believe that oral transmission of folktales happens through the replication of sequences of motifs. Darányi et al. [16] handle motif strings like chromosome mutations in genetics. Kawakami et al. [27] cover 23 Japanese texts of Cinderella tales, whilst Swartjes et al use Little Red Riding Hood as one of their examples [37].

Our text is organized as follows. Section 2 presents the two classic variants of AT 333. Section 3 summarizes additional variants. Section 4 has our analysis of the variant-formation phenomenon, with special attention to the interaction among types, explained in terms of semiotic relations. Section 5 describes a simple plan-recognition prototype working over variant libraries. Section 6 contains concluding remarks. The full texts of the variants cited in the text are available in a separate document. ${ }^{1}$

\title{
2 The two classic variants
}

In the Index, the type of interest, AT 333, characteristically named The Glutton, is basically described as follows, noting that two major episodes are listed [1, p. 125]:

The wolf or other monster devours human beings until all of them are rescued alive from his belly.

I. Wolf's Feast. By masking as mother or grandmother the wolf deceives and devours a little girl whom he meets on his way to her grandmother's.

\footnotetext{
${ }^{1}$ http://www-di.inf.puc-rio.br/ furtado/LRRH_texts.pdf
} 
II. Rescue. The wolf is cut open and his victims rescued alive; his belly is sewed full of stones and he drowns, or he jumps to his death.

The first classic variant, Le Petit Chaperon Rouge (Little Red Riding Hood), was composed in France in 1697, by Charles Perrault [33], during the reign of Louis $\mathrm{XIV}^{\text {th }}$. It consists of the first episode alone, so that there is no happy ending, contrary to what children normally expect from nursery fairy tales. The little girl, going through the woods to see her grandmother, is accosted by the wolf who reaches the grandmother's house ahead of her. The wolf kills the grandmother and takes her place in bed. When the girl arrives, she is astonished at the "grandmother"'s large, ears, large eyes, etc., until she asks about her huge teeth, whereat the wolf gobbles her up. Following a convention of the genre of admonitory fables, a "moralité" is appended, to the effect that well-bred girls should not listen to strangers, particularly when they pose as "gentle wolves"

The second and more influential classic variant is that of the brothers Grimm (Jacob and Wilhelm), written in German, entitled Rotkäppchen (Little Red Cap) [22], first published in 1812. The girl's question about the wolf's teeth is replaced by: "But, grandmother, what a dreadful big mouth you have!" This is a vital change - not being bitten, the victims are gobbled up alive - and so the Grimm variant can encompass the two episodes prescribed for the AT 333 type. Rescue is effected by a hunter, who finds the wolf sleeping and cuts his belly, allowing girl and grandmother to escape. The wolf, his belly filled with heavy stones fetched by the girl, wakes up, tries to run away and falls dead, unable to carry the weight. As a moral addendum to the happy ending, the girl promises to never again deviate from the path when so ordered by her mother. Having collected the story from two distinct sources, the brothers wrote a single text with a second finale, wherein both female characters show that they had learned from their experience with the villain. A second wolf comes in with similar proposals. The girl warns her grandmother who manages to keep the animal outside, and eventually they cause him to fall from the roof into a trough and be drowned.

\section{Some other variants}

In [38] no less than 58 folktales were examined as belonging to type AT 333 (and AT 123). Here we shall merely add seven tales to the classic ones of the previous section.

Since several variants do not mention a red hood or a similar piece of clothing as attribute of the protagonist, the conjecture was raised that this was Perrault's invention, later imitated by the Grimms. However a tale written in Latin by Egbert de Liège in the $11^{\text {th }}$ century, De puella a lupellis seruata (About a Girl Saved from Wolf Cubs) [43], arguably prefiguring some characteristics of AT 333, features a red tunic which is not merely ornamental but plays a role in the events. The girl had received it as a baptismal gift from her godfather. When she was once captured by a wolf and delivered to its cubs to be eaten, she suffered no harm. The virtue of baptism, visually represented by the red tunic, gave her protection. The cubs, their natural ferocity sub- 
dued, gently caressed her head covered by the tunic. The moral lesson, in this case, is consonant with the teaching of the Bible (Daniel VI, 27).

Whilst in the variants considered so far the girl is presented as naive, in contrast to the clever villain, the situation is reversed in the Conte de la Mère-grand (The Story of Grandmother), collected by folklorist Achille Millien in the French province of Nivernais, circa 1870, and later published by Paul Delarue [18]. In this variant, which some scholars believe to be closer to the primitive oral tradition, the villain is a "bzou", a werewolf. After killing and partly devouring the grandmother's body, he stores some of her flesh and fills a bottle with her blood. When the girl comes in, he directs her to eat and drink from these ghastly remains. Then he tells her to undress and lie down on the bed. Whenever the girl asks where to put each piece of clothing, the answer is always: "Throw it in the fire, my child; you don't need it anymore." In the ensuing dialogue about the peculiar physical attributes of the fake grandmother, when the question about her "big mouth" is asked the bzou gives the conventional reply: "All the better to eat you with, my child!" - but this time the action does not follow the words. What happens instead is that the girl asks permission to go out to relieve herself, which is a ruse whereby she ends up outsmarting the villain and safely going back to home (cf. http://expositions.bnf.fr/contes/gros/chaperon/nivers.htm).

An Italian variant published by Italo Calvino, entitled Il Lupo e le Tre Ragazze (The Wolf and the Three Girls) [7], adopts the trebling device [34] so common in folktales, making three sisters, one by one, repeat the action of taking victuals to their sick mother. The wolf intercepts each girl but merely demands the food and drink that they carry. The youngest girl, who is the protagonist, throws at the wolf a portion that she had filled with nails. This infuriates the wolf, who hurries to the mother's house to devour her and lay in wait for the girl. After the customary dialogue with the wolf posing as the mother, the animal also swallows the girl. The townspeople observe the wolf coming out, kill him and extract mother and girl alive from his belly. But that is not all, as Calvino admits in an endnote. Having found the text as initially collected by Giambattista Basile, he had deliberately omitted what he thought to be a too gruesome detail ("una progressione troppo truculenta"): after killing the mother, the wolf had made "a doorlatch cord out of her tendons, a meat pie out of her flesh, and wine out of her blood". Repeating the strange above-described episode of the Conte de la Mère-grand, the girl is induced to eat and drink from these remains, with the aggravating circumstance that they belonged to her mother, rather than to a more remotely related grandparent.

Turning to China, one encounters the tale Lon Po Po (Grammie Wolf), translated by Ed Young [42], which again features three sisters but, unlike the Western folktale cliché, shows the eldest as protagonist, more experienced and also more resourceful than the others. The mother, here explicitly declared to be a young widow, goes to visit the grandmother on her birthday, and warns Shang, the eldest, not to let anyone inside during her absence. A wolf overhears her words, disguises as an old woman and knocks at the door claiming to be the grandmother. After some hesitation, the girls allow him to enter and, in the dark, since the wolf claims that light hurts his eyes, they go to bed together. Shang, however, lighting a candle for a moment catches a glimpse of the wolf's hairy face. She convinces him to permit her two sisters to go 
outside under the pretext that one of them is thirsty. And herself is also allowed to go out, promising to fetch some special nuts for "Grammie". Tired of waiting for their return, the wolf leaves the house and finds the three sisters up in a tree. They persuade him to fetch a basket mounted on which they propose to bring him up, in order to pluck with his own hands the delicious nuts. They pull on the rope attached to the basket, but let it go so that the wolf is seriously bruised. And he finally dies when the false attempt is repeated for the third time.

Another Chinese variant features a bear as the villain: Hsiung chia $P^{`} \circ$ (Goldflower and the Bear) [11], translated by Chiang Mi. The crafty protagonist, Goldflower, is once again an elder sister, living with her mother and a brother. The mother leaves them for one day to visit their sick aunt, asking the girl to take care of her brother and call their grandmother to keep them company during the night. The bear knocks at the door, posing as the grandmother. Shortly after he comes in, the girl - in spite of the darkness - ends up disclosing his identity. She manages to lock the boy in another room, and then obeys the bear's request to go to bed at his side. The villain's plan is to eat her at midnight, but she asks to go out to relieve her tummy. As distrustful as the werewolf in the before-mentioned French variant, the bear ties one end of a belt to her hand - an equally useless precaution. Safely outside on top of a tree, Goldflower asks if he would wish to eat some pears, to be plucked with a spear, which the famished beast obligingly goes to fetch in the house. The girl begins with one fruit, but the next thing to be thrown into his widely open gullet is the spear itself. Coming back in the morning, the mother praises the brave little Goldflower.

One variant, published in Portugal by Guerra Junqueiro, entitled $O$ Chapelinho Encarnado [23], basically follows the Grimm brothers pattern. A curious twist is introduced: instead of luring the girl to pick up wild flowers, the wolf points to her a number of medicinal herbs, all poisonous plants in reality, and she mistakes him for a doctor. At the end, the initiative of filling the belly of the wolf with stones is attributed not to the girl, but to the hunter, who, after skinning the animal, merrily shares the food and drink brought by the girl with her and her grandmother.

The highly reputed Brazilian folklorist Camara Cascudo included in his collection [8] a variant, $O$ Chapelinho Vermelho, which also follows the Grimm brothers pattern. The mother is introduced as a widow and the name of the girl is spelled out: Laura. Although she is known, as the conventional title goes, by a nickname translatable as "Little Red Hat", what she wears every day is a red parasol, given by her mother. One more particularity is that, upon entering her grandmother's house, the girl forgets to close the door, so that finding the door open is what strikes the hunter as suspicious when he approaches the house. The hunter bleeds the wolf with a knife and, noticing his distended belly, proceeds to open it thus saving the two victims. Nothing is said about filling the wolf's belly with stones, the wounds inflicted by the hunter's knife having been enough to kill him. Two prudent lessons are learned: (1) Laura would not forget her mother's recommendation to never deviate from the path, the specific reason being given here that there existed evil beasts in the wood; (2) living alone should no longer be an option for the old woman, who from then on would dwell with her daughter and granddaughter. 


\section{Comments on the formation of variants}

It is a truism that people tend to introduce personal contributions when retelling a story. There are also cultural time and place circumstances that require adaptations; for example, in the Arab world the prince would in no way be allowed to meet Cinderella in a ballroom - he falls in love without having ever seen her (cf. "Le Bracelet de Cheville" in the Mardrus translation of One Thousand and One Nights [31]). Other differences among variants may result from the level of education of the oral storytellers affecting how spontaneous they are, and the attitude of the collectors who may either prefer to reproduce exactly what they hear or introduce corrections and rational explanations while omitting indecorous or gruesome scenes. On the storyteller's part, however, this tendency is often attenuated by an instinctive pact with the audience with children, in special - in favour of faithful repetition, preferably employing the very same words. Indeed the genre of folktales is strongly marked by conventions which, to a remarkable extent, remain the same in different times and places. The folklorist Albert Lord called tension of essences the compulsion that drives all singers (i.e. traditional oral storytellers) to strictly enforce such conventions [29, p. 98]:

\footnotetext{
In our investigation of composition by theme this hidden tension of essences must be taken into consideration. We are apparently dealing here with a strong force that keeps certain themes together. It is deeply imbedded in the tradition; the singer probably imbibes it intuitively at a very early stage of his career. It pervades his material and the tradition. He avoids violating the group of themes by omitting any of its members. [We shall see] that he will even go so far as to substitute something similar if he finds that for one reason or another he cannot use one of the elements in its usual form.
}

The notion of tension of essences may perhaps help explaining not only the total permanence of some variants within the frontiers of a type, but also the emergence of transgressive variants, which absorb features pertaining to other types, sometimes even provoking a sensation of strangeness. When an oral storyteller feels the urge "to substitute something similar" in a story, the chosen "something" should, as an effect of the tension-of-essences forceful compulsion, still belong to the folktale genre - but what if the storyteller's repertoire comprises more than one folktale type? As happens with many classifications, the frontiers between the types in the Index are often blurred, to the point that one or more motifs can be shared and some stories may well be classified in more than one type. So a viable hypothesis can be advanced that some variants did originate through, so to speak, a type-contamination phenomenon.

Accordingly we propose to study type interactions as a possible factor in the genesis of variants. We shall characterize the interactions that may occur among types, also involving motifs, by way of semiotic relations, taking an approach we applied before to the conceptual modelling of both literary genres and business information systems $[12,25,20]$. We distinguish four kinds of semiotic relations, associated with the so-called four master tropes [6, 10], whose significance has been cogently stressed by a literary theory scholar, Jonathan Culler, who regards them "as a system, 
indeed the system, by which the mind comes to grasp the world conceptually in language" [15, p. 72]. For the ideas and for the nomenclature in the table below, we are mainly indebted to the pioneering semiotic studies of Ferdinand de Saussure [35]:

\begin{tabular}{llll} 
relation & meaning & operator & trope \\
\hline syntagmatic & connection & and & metonymy \\
paradigmatic & similarity & or & metaphor \\
meronymic & unfolding & part-whole & synecdoche \\
antithetic & opposition & not & irony
\end{tabular}

The itemized discussion below explores the meaning of each of the four semiotic relations, as applied to the derivation of folktale type variants stemming from AT 333 .

(1) Syntagmatic relation with type AT 123. As mentioned at the beginning of section 2, the Index describes type AT 333 as comprising two episodes, namely Wolf's Feast and Rescue, but the classic Perrault variant does not proceed beyond the end of the first episode. As a consequence, one is led to assume that the Rescue episode is not essential to characterize AT 333. On the other hand the situation created by Wolf's Feast is a long distance away from the happy-ending that is commonly expected in nursery fairy tales. A continuation in consonance with the Rescue episode, exactly as described in the Index, is suggested by AT 123: The Wolf and the Kids, a type pertaining to the group of Animal Tales, which contains the key motif F913: Victims rescued from swallower's belly.

The connection (syntagmatic relation) whereby AT 123 complements AT 333 is explicitly declared in the Index by "cf." cross-references [1, p. 50, p. 125]. Moreover the Grimm brothers variant, which has the two episodes, is often put side by side with another story equally collected by them, The Wolf and the Seven Little Kids [22], clearly of type AT 123.

Still it must be noted that several of the variants reported here do not follow the Grimm pattern in the Rescue episode. They diverge with respect to the outcome, which, as seen, may involve the death of the girl, or her rescue after being devoured, or even her being totally preserved from the villain's attempts either by miraculous protection or by her successful ruses.

(2) Paradigmatic relation with type AT 311B*. For the Grimm variant, as also for those that follow its pattern (e.g. the Italian and the two Portuguese variants in section 3), certain correspondences or analogies can be traced with variants of type AT 311B*: The Singing Bag, a striking example being another story collected in Brazil by Camara Cascudo [8], A Menina dos Brincos de Ouro (The Girl with Golden Earrings). Here the villain is neither an animal nor a werewolf; he is a very ugly old man, still with a fearsome aspect but no more than human. The golden earrings, a gift from her mother, serve as the girl's characteristic attribute and have a function in the plot. As will be noted in the summary below, the villain's bag becomes the wolf's belly of the Grimm variant, and what is done to the bag mirrors the act of cutting the belly and filling it with stones. In this sense, the AT 311B* variant replaces the Grimm variant.

One day the girl went out to bring water from a fountain. Having removed her earrings to wash herself, she forgot to pick them up before returning. Afraid to be reprimanded by her mother, she walked again to the fountain, where she was caught by the villain and sewed inside a bag. The man intended to use her to make a living. At each house that he visited, he advertised the magic bag, which would sing when he menaced to strike it with his staff. Everywhere 
people gave him money, until he came inadvertently to the girl's house, where her voice was recognized. He was invited to eat and drink, which he did in excess and fell asleep, whereat the bag was opened to free the girl and then filled with excrement. At the next house visited, the singing bag failed to work; beaten with the staff, it ruptured spilling its contents.

(3) Meronymic relation with type AT 437. In The Story of Grandmother the paths taken by the girl and the werewolf to reach the old lady's house are called, respectively, the Needles Road and the Pins Road. And, strangely enough, while walking along her chosen path, the little girl "enjoyed herself picking up needles" [18]. Except for this brief and puzzling mention, these objects remain as meaningless details, having no participation in the story.

And yet, browsing through the Index, we see that needles and pins are often treated as wondrous objects (motifs D1181: Magic Needle and D1182: Magic Pin). And traversing the Index hierarchy upwards, from motifs to types, we find them playing a fundamental role in type AT 437: The Needle Prince (also named The Supplanted Bride), described as follows [1, p. 140]: "The maiden finds a seemingly dead prince whose body is covered with pins and needles and begins to remove them ... ". Those motifs are thus expanded into a full narrative in AT 437.

Especially relevant to the present discussion is a variant from Afghanistan, entitled The Seventy-Year-Old Corpse reported by Dorson [17], which has several elements in common with the AT 333 variants. An important difference, though, also deserves mention: the girl lives alone with her old father, who takes her to visit her aunt. We are told that, instead of meeting the aunt, the girl finds a seventy year old corpse covered with needles, destined to revive if someone would pick the needles from his body. At the end the girl marries the "corpse", whereas no further news are heard about her old father, whom she had left waiting for a drink of water. One is tempted to say that Bruno Bettelheim would regard this participation of two old males, the father and the daunting corpse, as an uncannily explicit confirmation of the presence - in two different forms - of the paternal figure, in an "externalization of overwhelming oedipal feelings, and ... in his protective and rescuing function" [4, p. 178].

(4) Antithetic relation with type AT 449. Again in The Story of Grandmother we watch the strange scene of the girl eating and drinking from her grandmother's remains, punctuated by the acid comment of a little cat: "A slut is she who eats the flesh and drinks the blood of her grandmother!" The scene has no consequence in the plot, and in fact it is clearly inconsistent with the role of the girl in type AT 333. It would sound natural, however, in a type in opposition to AT 333, such as AT 449: The Tsar's Dog, wherein the roles of victim and villain are totally reversed. The cannibalistic scene in The Story of Grandmother has the effect of assimilating the girl to a ghoul (motif G20 in the Index), and the female villain of the most often cited variant of type AT 449, namely The Story of Sidi Nouman (cf. Andrew Lang's translation in Arabian Nights Entertainment) happens to be a ghoul.

No less intriguing in The Story of Grandmother are the repartees in the ensuing undressing scene, with the villain (a werewolf, as we may recall) telling the girl to destroy each piece of clothing: "Throw it in the fire, my child; you don't need it anymore." This, too, turns out to be inconsequential in the plot, but was a major concern in the werewolf historical chronicles and fictions of the Middle Ages [2, 36]. In 1521, the Inquisitor-General for the diocese of Besançon heard a case involving a certain Pierre Bourget [2]. He confessed under duress that, by smearing his body with a salve given by a demon, he became a wolf, but "the metamorphosis could not take place with him unless he were stark naked". And to recover his form he would "beat a retreat to his clothes, and smear himself again". Did the werewolf in The Story of Grandmother 
intend to transform the girl into a being of his species? Surely the anonymous author did not mean that, but leaving aside the norms of AT 333 the idea would not appear to be so farfetched.

In this regard, also illustrating type AT 449, there are two medieval lays (short narrative poems) that deserve our attention. They are both about noble knights with the ability to transform themselves into wolves. In the two narratives, they are betrayed by their villainous wives, intent on permanently preventing their resuming the human form. In Marie de France's lay of Bisclavret [30] - an old Breton word signifying "werewolf" - the woman accomplishes this effect by stealing from a secret hiding place the man's clothes, which he needed to put on again to undo the transformation. In the other example, the anonymous lay of Melion [5], after a magic ring is applied to break the enchantment, the man feels tempted to punish the woman by inflicting upon her the same metamorphosis.

In the preceding discussion we purported to show how types can be semiotically related, and argued that such relations constitute a factor to be accounted for in the emergence of variants. We should add that types may be combined in various ways to yield more complex types, whose attractiveness is heightened by the occurrence of unexpected changes. Indeed Aristotle's Poetics ${ }^{2}$ distinguishes simple and complex

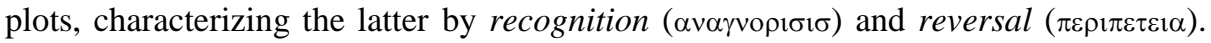
Differently from reversal, recognition does not imply that the world changed, but that the beliefs of the characters about themselves and the current facts were altered.

In particular, could a legitimate folktale promote the union of monster and girl? Could we conciliate type AT 333 (where the werewolf is a villain) with the antithetically related medieval lays of type AT 449 (where the werewolf is the victim)? Such conciliations of opposites are treated under the topic of blending [19], often requiring creative adaptations. A solution is given by type AT 425C: Beauty and the Beast. At first the Beast is shown as the villain, claiming the life of the merchant or else of one of his daughters: "Go and see if there's one among them who has enough courage and love for you to sacrifice herself to save your life" [41, p. 159] - but then proves to be the victim of an enchantment. Later, coming to sense his true inner nature (an event of recognition, as in Aristotle), Belle makes him human again by manifesting her love (motif D735-1: Disenchanting of animal by being kissed by woman). So, it is as human beings that they join.

Alternatively, we might combine AT 333 and AT 449 by pursuing until some sort of outcome the anomalous passages of The Story of Grandmother, allowing the protagonists to join in a non-human form. The werewolf feeds human flesh of his victim to the girl, expecting that she would transform herself like he did (as Melion for a moment thought to cast the curse upon his wife), thereby assuming a shape that she would keep forever once her clothes were destroyed (recall the concern of Pierre Bourget to "beat a retreat to his clothes", and the knight's need to get back his clothes in Bisclavret). At the end the two werewolves would marry and live happily forever after, as a variant of an admittedly misbegotten new type (of, perhaps, a modern appeal, since it would also include among its variants the story of the happy vampires Edward and Bella in the Twilight Saga: http://twilightthemovie.com/).

\footnotetext{
${ }^{2}$ http://www.gutenberg.org/files/1974/1974-h/1974-h.htm
} 


\section{$5 \quad$ First steps towards variants in computer-generated stories}

To explore in a computer environment the variants of folktale types, kept in a library of typical plans, we developed a system in $C \#$ that does plan-recognition over the variants of the type indicated (e.g. AT 333), with links to pages of semiotically related types (e.g. AT 123, AT 311B*, AT 437, AT 449). Plan-recognition involves matching a number of actions against a pre-assembled repertoire of plot patterns (cf. [20, 25]).

Let $P$ be a set of $m$ variants of a specific tale type that are represented by complete plans, $P=\left\{P_{1}, P_{2}, \cdots, P_{m}\right\}$, where each plan is a sequence of events, i.e.: $P_{i}=$ $\left\langle e_{1}^{i}, e_{2}^{i}, \cdots, e_{n_{i}}^{i}\right\rangle$. These events are actions with ground arguments that are story elements (specific names, places, and objects). For instance, $P_{\mathrm{k}}=\langle$ go (Abel, Beach), meet(Abel, Cain), kill(Cain, Abel) $\rangle$. The library of typical plans is defined by associating each plan $P_{i}$ with the following elements: (1) the story title; (2) a set of parameterized terms akin to those we use in Logtell [14] to formalize Proppian functions - describing the story events; (3) the specification of the characters' roles (e.g. villain, victim, hero) and objects' functions (e.g. wolf's feast place, basket contents); (4) the semiotic relations of the story with other variants of same or different types (Section 4); (5) a text template used to display the story as text, wherein certain phrases are treated as variables (written in the format \#VAR $\#$ ); and (6) the comics resources used for dramatization, indicating the path to the folder that contains the images representing the characters and objects of the narrative and a set of event templates to describe the events textually. The library is specified in an XML file.

Let $T$ be a partial plan expressed as a sequence of events given by the user. The system finds plans in $P$ that are consistent with $T$. During the searching process, the arguments of the events in $P$ are instantiated. For example, with the input $T=$ $\{$ give(Anne, ring, Little Ring Girl), ask_to_take(Marie, Little Ring Girl, tea, Anne), eat(Joe, Little Ring Girl)\}, the following stories are generated:

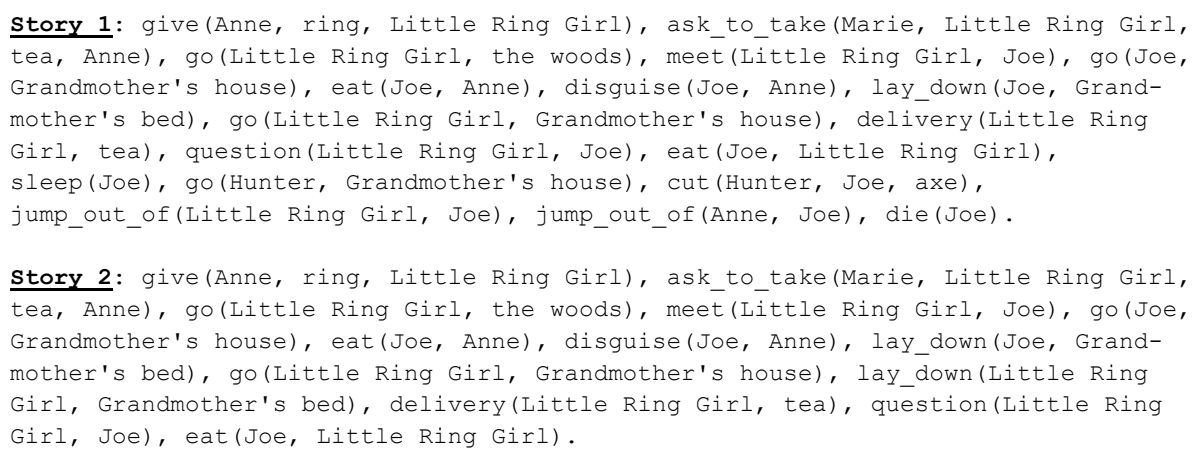

which correspond, respectively, to the Grimm and Perrault AT 333 variants, rephrased to display the names of characters and objects given by the user.

Our plan recognition algorithm employs a tree structure, which we call generalized plan suffix tree. Based on the suffix tree commonly used for string pattern matching [24], this trie-like data structure contains all suffixes $p_{k}$ of each plan in $P$. If a plan $P_{i}$ has a sequence of events $p=e_{1} e_{2} \cdots e_{k} \cdots e_{N}$, then $p_{k}=e_{k} e_{k+1} \cdots e_{N}$ is the suffix of $p$ 
that starts at position $k$ (we have dropped the index $i$ of the expressions $p$ and $p_{k}$ for the sake of simplicity). In a generalized plan suffix tree $S$, edges are labeled with the parameterized plan events that belong to each suffix $p_{k}$, and the leaves point to the complete plans ending in $p_{k}$. Each suffix is padded with a terminal symbol $\$ i$ that uniquely signals the complete plan in the leaf node. Figure 1 shows an example of generalized plan suffix tree generated for the plan sequences $P_{1}=\{\operatorname{go}(A, B)$, meet $(A, C)$, $\operatorname{kill}(C, A)\}$ and $P_{2}=\{\operatorname{tell}(A, B, C), \operatorname{meet}(A, C), \operatorname{go}(A, D)\}$.

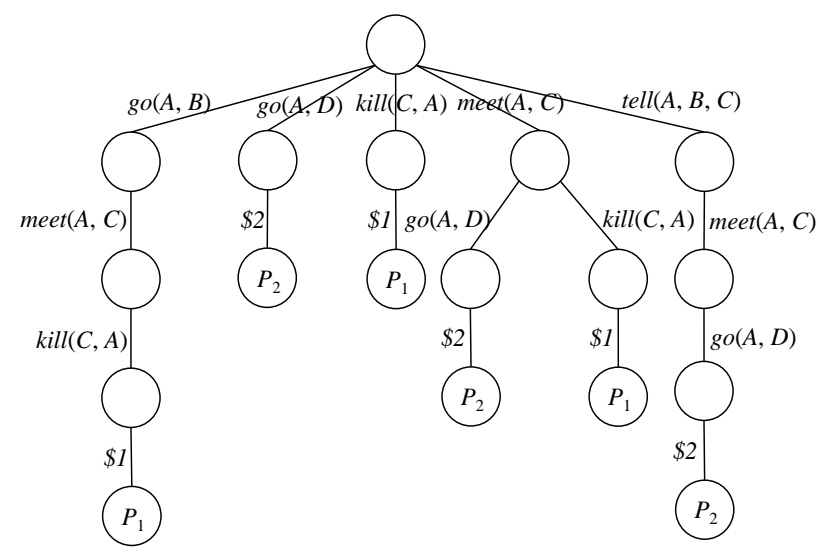

Fig. 1. Generalized plan suffix tree for $P_{1}=\{\operatorname{go}(A, B), \operatorname{meet}(A, C), \operatorname{kill}(C, A)\}$ and $P_{2}=\{\operatorname{tell}(A$, $B, C), \operatorname{meet}(A, C), \operatorname{go}(A, D)\}$..

The process of searching for plans that match a given partial plan $T$, expressed as a sequence of input terms, is straightforward: starting from the root node, the algorithm sequentially matches $T$ against the parameterized plan events on the edges of the tree, in chronological but not necessarily consecutive order, instantiating the event variables and proceeding until all input terms are matched and a leaf node is reached. If more solutions are requested, a backtracking procedure tries to find alternative paths matching $T$. The search process produces a set of complete plans $G$, with the event variables instantiated with the values appearing in the input partial plan or, for events not present in the partial plan, with the default values defined in the library.

After generating $G$ through plan-recognition, the system allows users to apply the semiotic relations (involving connection, similarity, unfolding, and opposition) and explore other variants of same or different types. The process of searching for variants uses the semiotic relations specified in the library of typical plans to create a link between a $g_{i}$ in $G$ and its semiotically related variants. When instantiating one such variant $v_{i}$, the event variables of $v_{i}$ are instantiated according to the characters and objects that play important roles in the baseline story $g_{i}$. Characters playing roles in $g_{i}$ that also exist in $v_{i}$, assume the same role in the variant. For roles that only exist in $v_{i}$, the user is asked to name the characters who would fulfil such roles.

Following the $g_{i} \rightarrow v_{i}$ links taken from the examples of section 4 , the user gains a chance to reinterpret the $g_{i}$ AT 333 variant, in view of aspects highlighted in the semiotically related $v_{i}$ : 1 . the wolf's villainy complemented by a rescue act (AT 123); 2 . 
the wolf and his belly replaced by ugly man and his bag (AT 311B*); 3. the girl's gesture of picking needles expanded to the wider scope of a disenchantment ritual (AT 437); 4. girl and werewolf with reversed roles of villain and victim (AT 449).

As illustrated in Figure 2, our system supports two dramatization modalities: text and comics. The former uses the original literary rendition of the matched typical plan as a template and represents the generated stories in text format. The latter offers a storyboard-like comic strip representation, where each story event gains a graphical illustration and a short sentence description. In the illustrations, the scene compositing automatic process takes into account the specific object carried by each character and the correct movement directions. More details on the generation of comic strips can be found in our previous work on interactive comics [28].

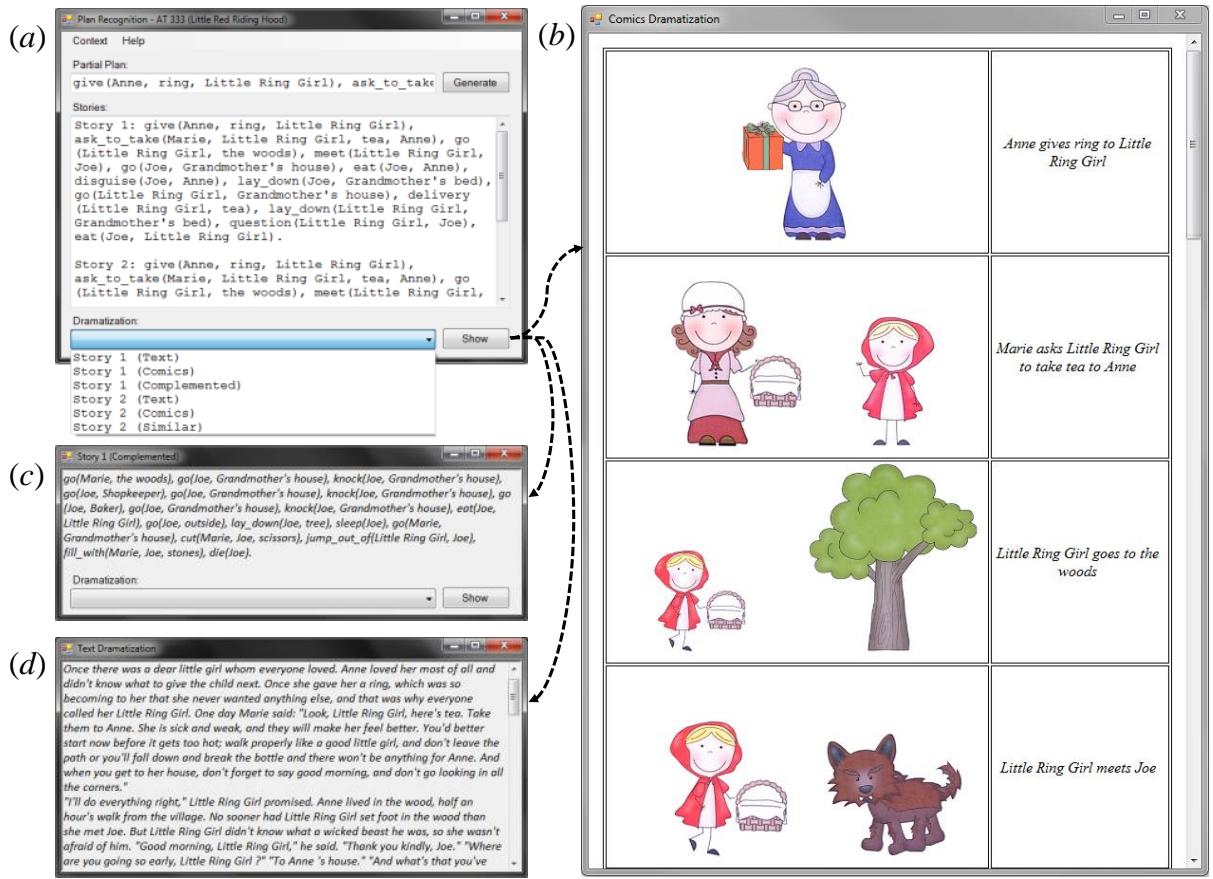

Fig. 2. Plan recognition system: (a) main user interface; $(b)$ comics dramatization; $(c)$ a variant for story 1 ; and $(d)$ text dramatization.

\section{Concluding remarks}

The imagination of storytellers far surpasses what automatic tools can produce at the current state of the art, but there is always a hope that technology can advance by the observation and analysis of human creative processes. Folktales offer a suitable model to begin with, given their amazing fertility in the proliferation of variants, favouring different - sometimes very different - perspectives to view what is basically the same story. Having access to a collection of variants, either of folktales or of some other 
similarly predefined genre, readers have a fair chance to find a given story in a treatment as congenial as possible to their tastes and personality profile.

Moreover, prospective amateur authors may feel inspired to put together new variants of their own after seeing how variants can derive from the type and motif interactions that we associate with semiotic relations. They would learn how new stories can arise from episodes of existing stories, through a process, respectively, of concatenation, analogous substitution, expansion into finer grained actions, or radical reversal.

Computer-based libraries, such as we described, should then constitute a vital first step in this direction. In special, by also representing the stories as plans, in the form of sequences of terms denoting the story events (cf. the second paragraph of section 5), we effectively started to combine the two approaches mentioned in the Introduction, namely Aarne-Thompson's types and motifs and Proppian functions, and provided a bridge to our previously developed Logtell prototypes [13,14,20,25].

We expect that our analysis of variants, stimulated by further research efforts in the line of computational narratology, may contribute to the design of semi-automatic methods for supporting interactive plot composition, to be usefully incorporated into digital storytelling systems.

\section{Acknowledgements}

This work was partially supported by CNPq (National Council for Scientific and Technological Development, linked to the Ministry of Science, Technology, and Innovation), CAPES (Coordination for the Improvement of Higher Education Personnel), FINEP (Brazilian Innovation Agency), ICAD/VisionLab (PUC-Rio), and Oi Futuro Institute.

\section{References}

1. Aarne, A., Thompson, S.: The Types of the Folktale. Acad. Scientiarum Fennica (1961).

2. Baring-Gould, S.: The Book of Were-Wolves: http://www.gutenberg.org/dirs/etext04/bofww10h.htm

3. Barthes, R.: Theory of the Text. In Untying the Text: a Post-Structuralist Reader. Young, J.C. (ed.). Routledge \& Kegan Paul (1981).

4. Bettelhein, B.: The Uses of Enchantment. Vintage (2010).

5. Burgess, G.S., Brook, L.C.: Eleven Old French Narrative Lays. D.S. Brewer (2007).

6. Burke, K.: A Grammar of Motives. Univ. of California Press (1969).

7. Calvino, I.: Italian Folktales. Mariner Books (1992).

8. Camara Cascudo, L.: Contos Tradicionais do Brasil. Global (2014).

9. Cavazza, M., Pizzi, D.: Narratology for Interactive Storytelling: A Critical Introduction. In: Proc. of the Third International Conference TIDSE, Springer (2006).

10. Chandler, D.: Semiotics: the Basics. London: Routledge (2002).

11. Chiang Mi.: Goldflower and the Bear. In:The Classic Fairy Tales. Tatar,M. Norton (1999).

12. Ciarlini, A., Barbosa, S.D.J., Casanova, M.A., Furtado, A.L.: Event relations in plot-based plot composition. In: Proc. of the Brazilian Symposium on Computer Games and Digital Entertainment (2008).

13. Ciarlini, A., Casanova, M.A., Furtado, A.L., Veloso, P.: Modeling interactive storytelling genres as application domains. Journal of Intelligent Information Systems, 35(3), 2010.

14. Ciarlini, A, Pozzer, C.T., Furtado, A.L., Feijo, B.: A logic-based tool for interactive generation and dramatization of stories. In: Proc. of the ACM-SIGCHI International Conference on Advances in Computer Entertainment Technology (2005). 
15. Culler, J.: The Pursuit of Signs: Semiotics, Literature, Deconstruction. Routledge (1981).

16. Darányi, S., Wittek, P., Forró, L.: Toward Sequencing 'Narrative DNA': Tale Types, Motif Strings and Memetic Pathways. In: Proc. of the Third Workshop on Computational Models of Narrative (2012).

17. Dorson, R.M.: Folktales Told Around the World. Univ. of Chicago Press (1978).

18. Delarue, P.: The Story of Grandmother. In Little Red Riding Hood: A Casebook. Dundes, A. (ed). Univ. of Wisconsin Press (1989).

19. Fauconnier, G. Turner, M.: Conceptual projection and middle spaces. Tech. Rep. 9401, Univ. California, San Diego (1994).

20. Furtado, A.L. and Ciarlini, A.: Constructing Libraries of Typical Plans. In: Proc. of the Conference on Advanced Information Systems Engineering (2001).

21. Furtado, A.L., Casanova, M.A., Barbosa, S.D.J.: A Semiotic Approach to Conceptual Modelling. In: Proc. of the $33^{\text {rd }}$ Int. Conf. on Conceptual Modeling (2014).

22. Grimm, J., Grimm, W.: The Complete Grimm's FairyTales. M. Hunt and J. Stern (trans.). Pantheon (1972).

23. Guerra Junqueiro, A.B.: Contos para a Infância: http://www.gutenberg.org/files/16429/16429$\mathrm{h} / 16429 . \mathrm{htm}$

24. Gusfield, D.: Algorithms on Strings, Trees, and Sequences. Cambridge Univ. Press (1997).

25. Karlsson, B., Furtado, A. L.: Conceptual Model and System for Genre-Focused Interactive Storytelling. In: 13th International Conference on Entertainment Computing (2014).

26. Karsdorp, F. et al.: In Search of an Appropriate Abstraction Level for Motif Annotations. In: Proc. of the Third Workshop on Computational Models of Narrative (2012).

27. Kawakami, S. et al.: On Modeling Conceptual and Narrative Structure of Fairytales. Proc. of 13th European-Japanese Conf. on Information Modelling \& Knowledge Bases (2003).

28. Lima, E.S., Feijó, B., Furtado, A.L., Barbosa, S.D.J., Pozzer, C.T., Ciarlini, A.: NonBranching Interactive Comics. In: Proc. of the 10th International Conference on Advances in Computer Entertainment Technology, pp. 230-245 (2013).

29. Lord, A.: The Singer of Tales. Harvard Univ. Press (2000).

30. Marie de France.: The Lais of Marie de France. Burgess, G.S. et al (tr.). Penguin (1999).

31. Mardrus, J.C.: (trans.). Les Mille et une Nuits. Bouquins Robert Laffont, v. 2 (1985).

32. Mani, I.: Computational Narratology. In: Handbook of Narratology, Hühn, P. et al (eds). De Gruyter (2014). [Also in: http://www.lhn.uni-hamburg.de/article/computational-narratology].

33. Perrault, C.: Little Red Riding Hood. In: Beauties, Beasts and Enchantment - Classic French Fairy Tales. J. R. Planché and J. Zipes (trans.). Meridian (1991).

34. Propp, V.: Morphology of the Folktale. Laurence, S. (trans.), Univ. of Texas Press (1968).

35. Saussure, F.: Cours de Linguistique Générale. C. Bally et al (eds.). Payot (1995).

36. Sconduto, L.A.: Metamorphoses of the Werewolf: A Literary Study from Antiquity Through the Renaissance. McFarland (2008).

37. Swartjes, I., Theune, M. Iterative authoring using story generation feedback: debugging or co-creation?. In: Interactive Storytelling (pp. 62-73). Springer (2009).

38. Tehrani, J.J.: The Philogeny of Little Red Riding Hood. PLOS ONE, v. 8, 11 (2013).

39. Thompson S.: The Folktale. Univ. of California Press (1977).

40. Uther, H.J.: The Types of International Folktales. Finish Acad. Science \& Letters (2011).

41. Villeneuve, G. The Story of Beauty and the Beast. In: Beauties, Beasts and Enchantment Classic French Fairy Tales. J. R. Planché and J. Zipes (trans.). Meridian (1991).

42. Young, E.: Lon Po Po: A Red-Riding Hood Story from China. Puffin (1996).

43. Ziolkowski, J.M.: A Fairy Tale from before Fairy Tales: Egbert of Liège's 'De puella a lupellis seruata' and the Medieval Background of 'Little Red Riding Hood'. In: Speculum, v. 67, n. 3 (1992). 